\title{
Kitchen waste management by vermicomposting using locally available epigeic earthworm species
}

\section{Deepshikha Sharma}

Department of Environmental Science, Govt. Degree College, Kathua-184101(J\&K), India

E-mail: deepshiusa@gmail.com

\section{Article Info}

DOI: 10.31018/jans.v11i2.2058

Received: April 12, 2019

Revised: May 10, 2019

Accepted: May 15, 2019

\section{How to Cite}

Sharma, D. (2019). Kitchen waste management by vermicomposting using locally available epigeic earthworm species. Journal of Applied and Natural Science, 11(2): 372- 374 https://doi.org/10.31018/ jans.v11i2.2058 addition of kitchen waste. The average values of macronutrients in the vermicompost produced by $O$. tyrtaeum were observed to be the highest among all types of vermicomposts i.e. Organic Carbon (OC)- $11.66 \pm 0.34 \%$, Nitrogen (N)- $1.17 \pm 0.20 \%$, Phosphorus (P) $-2.97 \pm 0.32 \%$, Potassium (K)- $1.18 \pm 0.15 \%$, Calcium (Ca)- $0.26 \pm 0.04 \%$, Magnesium $(\mathrm{Mg})-0.17 \pm 0.04 \%$.

Keywords: Kitchen waste, Earthworms, Physico-chemical, Vermicompost.

\section{INTRODUCTION}

Kitchen waste is mainly composed of biodegradable wastes like cooked food wastes i.e. leftover chapattis, pulses, rice, pickles, vegetables, fruit peelings, tea leaves, ash, egg shells, bones, paper and non-biodegradable wastes like plastic, glass, packing, rubber and metals. Kitchen waste is found to be reused in most of the households as animal and poultry feed. Ashes were found to be utilized for cleaning utensils. Other wastes including paper, bottles, metal bins, plastic carry bags etc can be reused or recycled. Resources can be recovered from wastes using existing technologies and India has extremely effective recycling traditions (Sunil Kumar et al. 2017). As per CPCB Annual Review Report on Implementation of Solid Waste Management Rules, 2016 published in May 2017 , the total waste generation in J\&K state is 1634.50 TPD (622.50 Jammu and 1012.00 Srinagar). 1388.70 TPD waste is collected and only 3.45 TPD (Jammu) is treated out of the total waste generated. No proper segregation of waste is done and waste is simply collected and dumped unscientifically. A major portion of this waste generated comprises of kitchen waste. The biodegradable wastes like wastes from vegetables, fruits, tea leaves, food wastes etc. can be cultured with earthworms to form the vermicompost by using vermitechnology thereby reducing it at the source of its generation. This vermicompost can replace chemical fertilizers for growing plants. Of various methods, vermitechnology is one of the promising technologies for the management of organic waste. Vermitechnology is the process by which biological degradation of organic waste takes place in control conditions due to earthworm feeding on the materials (Kumar, 2005). This technology can also be used for the management of kitchen waste. In the present study an attempt has been made to produce vermicompost from kitchen waste using local species of earthworms from Jammu namely Amynthus diffringens, Metaphire houlleti and Octolasion tyrtaeum. The physico-chemical analysis of vermicompost produced by different species and the soil which was initially added to the vermibed was carried out and compared with each other.

\section{MATERIALS AND METHODS}

Three epigeic species of earthworms were collected form moist soils at the depth of 3 to $10 \mathrm{~cm}$ from the different locations of Jammu. The specimens of these earthworm species were sent to Zoologi- 
Sharma, D. et al. / J. Appl. \& Nat. Sci. 11(2): 372- 374 (2019)

cal Survey of India (ZSI), Calcutta for their identification. The species were identified as $A$. diffringens, M. houlleti and O. tyrtaeum. Specific vermibeds were prepared for specific earthworm species. A replica of three vermibeds for each species was prepared in the wooden boxes of size $0.40 \mathrm{~m} \times 0.30 \mathrm{~m} \times 0.26 \mathrm{~m}$. Each vermibed was prepared by placing a layer of paddy straw and saw dust at the base followed by a layer of sand and garden soil. Then each vermibed was inoculated with $50 \mathrm{gms}$ of medium sized earthworms of specific species. $1.5 \mathrm{~kg}$ of kitchen waste was chopped into small pieces before transferring it into vermibeds. This organic waste was transferred into vermibeds slowly in a period of 2 to 3 days. Then, these wooden boxes were covered with gunny bags and sprinkling of water was done at regular intervals to maintain desired moisture in the vermibeds till the vermicompost formation takes place. Also the temperature was monitored regularly in the vermibeds. After the formation of vermicompost, the sprinkling of water was stopped to ensure the migration of earthworms to deeper layers of vermibed. Then, the vermicompost was harvested, oven dried, crushed and sieved. The vermicompost produced by $A$. diffringens was named as VKA while the vermicompost produced by $M$. houlleti and O. tyrtaeum was named as VKM and VKO respectively.

The physico-chemical analysis of specific vermicomposts harvested using specific earthworm species was conducted for various parameters. The analysis was carried out using various methods like Kjeldahl method for nitrogen (Piper, 1944), Walkley and Black's rapid titration technique (Piper, 1944 and Jackson, 1958) for organic carbon, Olsen method (Gupta and Jalali, 1998) for phosphorus, Flame photometric method (Piper, 1944) for potassium and EDTA Titrimetric method (Gupta and Jalali, 1998) while the $\mathrm{pH}$ and electrical conductivity was analysed on $\mathrm{pH}$ meter and conductivity meter. The data was then compiled and average value of nutrient status of specific vermicompost was calculated. The physicochemical analysis of various types of vermicomposts i.e- vermicompost produced by $A$. Diffringens, M. houlleti and $O$. tyrtaeum was carried out by using standard methods given above. Also the physico-chemical analysis of original soil sample, which has been added in vermibed prior to earthworm inoculation and addition of kitchen waste, was done. Also the carbon-nitrogen ratio of each type of vermicompost was calculated.

\section{RESULTS AND DISCUSSION}

Epigeic earthworm species which were used in vermicomposting of kitchen waste were identified as $A$. diffringens (Baird, 1869), M. houlleti (Perrier) and $O$. tyrtaeum (Savigny, 1826). The average values of the macro nutrients (\%age) like organic

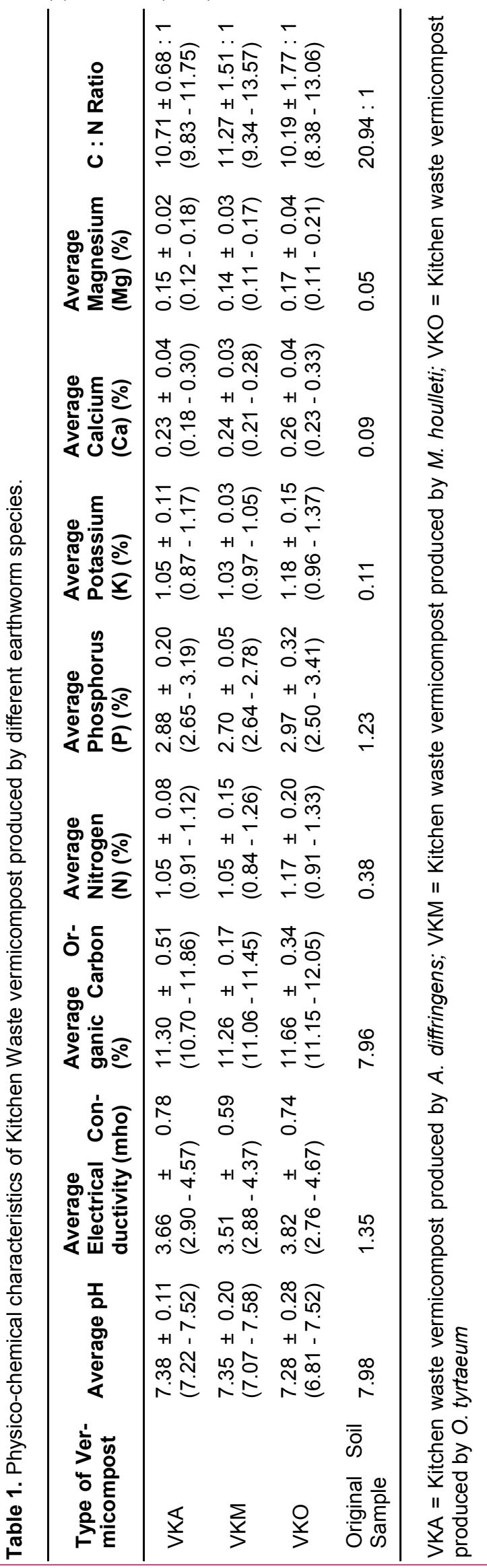


carbon, nitrogen, phosphorous, potassium, calcium and magnesium were observed to be for the different vermicompost (VKA, VKM and VKA) and the original soil sample are given in Table 1.

The study revealed that the average $\mathrm{pH}$ value of all the vermicomposts was less as compared to original soil sample. While least $\mathrm{pH}$ value (i.e 7.28 \pm 0.28 ) was observed in the kitchen waste vermicompost produced by $O$. tyrtaeum. The average electrical conductivity was observed to increase two fold in all vermicomposts produced by different species of earthworms on kitchen waste as compared to that of original soil sample added to the vermibed initially. The increase in electrical conductivity $(\mathrm{VKA}=3.66 \pm 0.78, \mathrm{VKM}=3.51 \pm 0.59$ and $\mathrm{VKO}=3.82 \pm 0.74$ ) was due to freely available ions and minerals that got compounded during ingestion and defecation by the earthworms (Table 1). Lakshmibai and Vijaylakshmi (2000) also observed increase in electrical conductivity during vermicomposting of sugar factory filter press mud using African earthworm species Eudrilus eugeniae.

The value of macronutrients was observed to increase approximately two folds in the vermicomposts produced by specific species on kitchen waste as compared to that of original soil sample, while the maximum percentage of macronutrients were observed in kitchen waste vermicomposts produced by $O$. tyrtaeum among the three species. The present observation is supported by the work of earlier workers like Rajpal et al., 2012 compared the indigenous species (Perionyx sansibaricus, $P$. excavatus) and exotic species (Eisenia fetida) to find their suitability in vermicomposting, Ponmani et al., 2014 worked on earthworm species E. eugeniae, Rai and Singh, 2013 worked on earthworm species Eisenia fetida, Sundararasu, 2019 worked on earthworm species $E$. eugeniae and reported more macro and micro nutrients in vermicomposts. The carbon: nitrogen ratio was observed to decrease in kitchen waste vermicomposts as compared with that of original soil sample. Although the minimum $\mathrm{C}$ : $\mathrm{N}$ ratio $(10.19 \pm 1.77$ : 1$)$ was observed in case of $O$. tyrtaeum among the vermicomposts produced by three species of earthworms, C: $\mathrm{N}$ ratio below 24 : 1 makes vermicomposts more fit for agriculture purpose (USDA, 2011).

\section{Conclusion}

The physico-chemical parameters of vermicompost produced by different epigeic species of earthworms named as VKA, VKM and VKO exhibited better nutrient value as compared with that of soil sample which has been added in vermibeds prior to earthworm inoculation and addition of kitchen waste. Moreover, the maximum percentage of macronutrients was observed in kitchen waste vermicompost (VKO) produced by O. tyrtaeum among the three species. Therefore, these vermicomposts produced by different local epigeic species of earthworms can be used as biofertilizers in the agricultural fields. The large quantity of kitchen waste can be properly managed with production of vermicompost using local species of earthworms and use of these biofertilizers in the agricultural fields can give a better plant growth without degrading the environment. Therefore, it is recommended that recycling of kitchen waste as composted manure should be done for its effective disposal and resource generation. In addition, vermicomposting of kitchen waste is a natural, ecofriendly, cost-benefitted and speedy process. Moreover using local species of earthworms in vermibeds will make the process of vermicomposting more efficient and economical.

\section{REFERENCES}

1. Gupta, J.P. and Jalali, V.K. (1998). Manual for Soil, Plant and Irrigation Water Analysis. Soil Science Section, SKUAST, Jammu.

2. Jackson, M.L. (1958). Soil Chemical Analysis. Prentice Hall of India Pvt. Ltd., New Delhi.

3. Kumar, A. (2005). Verms and Vermitechnology. A.P.H Publishing Corporation, New Delhi.

4. Kumar, S., Stephen, R.S. and Cheeseman, C. (2017). Challenges and opportunities associated with waste management in India. R. Soc. Open Sci. 4(3): 160764.

5. Lakshmibai, L. and G.S. Vijaylakshmi (2000). Vermicomposting of sugar factory filter press mud using on African earthworm species Eudrilus eugeniae (Kinberg) with a note on its physico-chemical features. Polln. Res. 19 (3): 481-483.

6. Piper, C.S. (1944). Soil and Plant Analysis. Interscience Publishers Inc., New York.

7. Ponmani, S., Udayasoorian, C., Jayabalakrishnan, R.M. and Kumar, K.V. (2014). Vermicomposting of paper mill solid waste using epigeic earthworm Eudrilus eugeniae. Journal of Environmental Biology, 35 (4), 617.

8. Rai, R. and Singh, K. (2013). Physico-chemical analysis of soil before and mixing with vermicompost of industrial effluents with different animal dung. International Journal of Agriculture Innovations and Research, 2(1), 112-116.

9. Rajpal, A., Bhargava, R., Sasi, S.K. and Chopra, A.K. (2012). Waste Management and Research. Sage Journals, 30(3), 266-275.

10.Sundararasu, K. (2019). Physico-chemical characterization of vermicompost and its impact on chilly plants (Capsicum annuum L.). International Journal of Research and Analytical Reviews, 6(1), 646-652.

11.USDA. (2011). Carbon to Nitrogen ratios in cropping systems. https://www.nrcs. usda.gov/wps/PA_NR CSConsumption/download?cid=nrcs142p2_0528 23\&ext=pdf. 